\title{
Rocuronium bromide: a pharmacological study
}

\author{
*Maaly M.H Gaafary, **Essam F. Al. Alkami \\ *Department of Anaesthesiology, Faculty of Medicine For Girls Al-Azhar University. \\ **Department of Pharmacology, Faculty of Medicine, Cairo University.
}

\begin{abstract}
This work was designed to assess the pharmacological effects of rocuronium. In either isolated preparation or intact animals. Rocuronium $(6-96 \mu \mathrm{g} / \mathrm{ml})$ caused a significant dose related reduction in the amplitude of rat phrenic nerve diaphragm contraction in response to indirect stimulation, the mean percentage reduction were statistically significant. The addition of neostgmine $(0.25 \mu \mathrm{g} / \mathrm{ml})$ caused complete reversal of the relaxant effect of rocuronium. In intact cat gastrocnemius sciatic nerve preparation rocuronium $(25-200 \mu \mathrm{g} / \mathrm{kg}$ ) caused dose dependent statiscally significant reduction. In comparing the drug with succinyl choline by the head drop method the mean time in second was $15.34 \pm 1.57$ and $10.44 \pm 0.91$ respectively.
\end{abstract}

\section{Introduction}

Rocuronium bromide is a neurom uscular relaxant with a short onset time, an intermediate duration of action and rapid recovery with cardiovascular stability [1]. In elderly patients, 0.9-mg $\mathrm{kg}^{-1}$ rocuronium does not produce any significant changes in heart rate, blood pressure, plasma catecholamine [2]. Its lack of histamine release is an important feature that accounts for its stable cardiovascular profile $[3,4]$. It is like vecuronium, a non depolarizing neurom -uscular blocking agent with mainly post junctional effect and high degree of selectivety for the receptors of the neuromuscular junction [5]. Muscle paralysis is produced by competitive antagonism of the nicotinic cholinergic receptors of skeletal muscles paralysis occur first in the well perfused fast muscles and late in the diaphragm. Onset of block is faster but less intense at the adductor muscles of the larynx than at the adductor pollicis [6], while the diaphragm muscle is affected later but recover earlier [7]. The rocuronium activity is terminated by gradual dissociation from the receptor shifting the agonist/antagonist equilibrium in favour of acetylcholine. Its action can be antagonized safely using $35 \mu \mathrm{gkg}^{-1}$ neostigmine [8]. Its potency is about 15$20 \%$ of vecuronium in animal and in human, the lower potency is an advan tage because it produced more rapid onset probably due to the higher molar concentration at the site of action [9].

In the present study, the pharm acological effect of rocuronium on an intact cats or isolated preparation was recorded to illustrate its main favou rable properties.

\section{Material And Methods}

In vitro experiments were designed to record:- 
a- Dose response curve: six rats of both sex weighting 200-250 gm were used isolated rat phrenic nerve diaphragm preparation (Bulbring, 1946) stimulated by an electric square pulse stimulator at a rate of 0 impulse per minute to avoid fatigue of the muscle. The duration was 200 icroseconds. The intensity of the stimulus was in the range of 5 volts for indirect nerve stimulation. The experim -ents were recorded for one minute then $1.5 \mu \mathrm{g} / \mathrm{ml}$ rocuronium bromide was incubated for 2 minutes and its effect on the responses of the preparation to indirect strimulation was recorded for 2 minutes then preparation. After complete recovery of the preparation the same procedure were repeated with different doses $3 \mu \mathrm{g} / \mathrm{ml}$ - $6 \mu \mathrm{g} / \mathrm{ml}$ $24 \mu \mathrm{g} / \mathrm{ml}-48 \mu \mathrm{g} / \mathrm{ml}-96 \mu \mathrm{g} / \mathrm{ml}$ and effect of each dose of rocuronium was investigated.

b- Cumulative effect was investigated without wash of organ preparation bath and reverse its effect by neostigmine.

\section{In vivo experiments:}

a- Intact cat gastrocnemius sciatic nerve preparation "Brown 1938" six cats of both sex weighting $1.5-3 \mathrm{~kg}$ were used.

The preparation was stimulated by an electronic square pulse stimulator at a rate of 12 impulse per minute. The pulse width was 1-2 milliseconds and the intensity of the stimulus was 4-6 volt. The electrically induced muscle contractions due to sciatic nerve stimulation were recorded for 1 minute, then rocuronium $12.5 \mu \mathrm{g} / \mathrm{kg}$ was incuba -ted for 2 minutes and its effects on the response of the preparation to the nerve stimulation was recorded for 2 minutes. After complete recovery of the prepa ration, the same procedure were repeat ed with different doses of rocuronium bromide $25 \mu \mathrm{g} / \mathrm{kg}, 50 \mu \mathrm{g} / \mathrm{kg}, 100 \mu \mathrm{g} / \mathrm{kg}$ and $200 \mu \mathrm{g} / \mathrm{kg}$ and their effects were recorded. b. Head drop method "Miller and Teunter 1944". Twelve male rabbits of $1.5 \mathrm{~kg}$ were used and divided into two groups (6 rabbits each one).

The head drop takes place when the head dropped foreward to the suppo rting surface of the inclosure, and could not raised in response to a light tap on rabbit back. The time which head drop had taken place was calculated. One group of rabbits were injected by $1 \mathrm{ml}$ "2.9 mg per second" rocuronium bromide, and other group were injected intravenously by $1 \mathrm{ml}$ " $4.9 \mathrm{mg}$ per sec ond" succinylcholine.

Statistical analysis of data was performed using :

1. For average values, arithmatic mean $\mathrm{X}=\frac{\mathrm{EX}}{\mathrm{N}}$

Where EX = sum of observed values, $\mathrm{N}=$ number of observations.

2. Standard error of the mean SEM = $\frac{\mathrm{S}}{\sqrt{\mathrm{N}}}$

Where $S$ is the square root of the sample variance or called the standard

deviation, $S=\sqrt{\frac{E X 2-(E X) 2 / M}{n-1}}$

Where EX2 = sum of squared values.

(EX)2 square of sum of values.

3. Test of significance $(t)=\frac{\text { mean }}{S E M}$

\section{Results}

1- In vitro studies:

a) Isolated rat phrenic nerve diaphragm preparations

Rocurronium (3 $\mu \mathrm{g} / \mathrm{ml}$ ) caused a reduction in the amplitude of contrac tions by $0.63 \pm 1.55 \%$. This reduction was statistically insignificant.

Rocuronium (6 $\mu \mathrm{g} / \mathrm{ml}, 12 \mu \mathrm{g} / \mathrm{ml}, 24$ $\mu \mathrm{g} / \mathrm{ml}, 48 \mu \mathrm{g} / \mathrm{ml}$ and $96 \mu \mathrm{g} / \mathrm{ml}$ ) caused a dose dependant reduction in the ampli - 
tude of rat phrenic nerve diaphragm contraction in response to indirect stimulation. The mean percentage reduction were $6.40 \pm 5.26 \%, 19.12$ $\pm 6.44 \%, 54.82 \pm 12.91 \%, 72 \pm 20.73 \%$, $95.35 \pm 11.39 \%$, respectively, These results were statistically significant [Table. (1), Fig ( 1)].

b) Cumulative effect of rocuronium bro -mide doses:

Cumulative effect of rocuronium bromide doses from $1.5 \mu \mathrm{g} / \mathrm{ml}$ to 96 $\mu \mathrm{g} / \mathrm{ml}$ on the rat phrenic nerve diaph ragm contraction was investigated, and the addition of neostigmine $(0.25$ $\mu \mathrm{g} / \mathrm{ml})$ which caused complete revew rsal of the relaxant effect of rocuronium fig.(2)

II- In vivo studies:

(a) Intact gastrocnemius sciatic nerve preparation:

Rocuronium $(12.5 \mu \mathrm{g} / \mathrm{kg})$ caused a reduction in the amplitude of contractions by $1.3 \pm 2.13 \%$, which was statistically insignificant.

Rocuronium $(25,50,100,200) \mu \mathrm{g} / \mathrm{kg}$ caused a dose dependent reduction in the amplitude of gastericnemius sciatic nerve contractions in response to indirect stimulation.

The mean percentage reduction were $(27.33 \pm 11.95 \%, 76.93 \pm 19.17 \%, 97.87$ $\pm 1.68 \%$, 100\%), respectively. These results were statistically significant [Table. (2), Fig. (3)].

(b) Rabbit head drop method:

The mean time ( sec.) for head drop produced by rocuronium $(2.9 \mathrm{mg} / \mathrm{l} \mathrm{sec}$ ) were $15.34 \pm 1.57 \mathrm{sec}$.

The mean time ( $s e c$.) for head drop produced by succinyl choline $(4.9 \mathrm{mg} / \mathrm{l}$ sec.) were $10.44 \pm 1.57 \mathrm{sec}$.

The mean time (sec.) for head drop produced by succinyl choline $(4.9 \mathrm{mg} / \mathrm{l}$ sec.) were $10.44 \pm 0.91 \mathrm{sec}$. Table (3) Fig. $(4 \& 5)$

Table (l): Effects of different doses $(1.5 \mu \mathrm{g} / \mathrm{ml}-96 \mu \mathrm{g} / \mathrm{ml})$ of rocuronium bromide on the rat phrenic nerve diaphragm preparation.

\begin{tabular}{|c|c|c|c|c|c|c|c|}
\hline \multirow{2}{*}{ No } & \multicolumn{7}{|c|}{ Doses } \\
\cline { 2 - 8 } & $1.5 \mu \mathrm{g} / \mathrm{ml}$ & $3 \mu \mathrm{g} / \mathrm{ml}$ & $6 \mu \mathrm{g} / \mathrm{ml}$ & $12 \mu \mathrm{g} / \mathrm{ml}$ & $24 \mu \mathrm{g} / \mathrm{ml}$ & $48 \mu \mathrm{g} / \mathrm{ml}$ & $96 \mu \mathrm{g} / \mathrm{ml}$ \\
\hline 1 & 0 & 0 & 9.00 & 26.90 & 65.30 & 90.00 & 100.00 \\
\hline 2 & 0 & 3.80 & 4.00 & 20.00 & 67.30 & 85.70 & 100.00 \\
\hline 3 & 0 & 0 & 6.90 & 18.60 & 61.30 & 69.00 & 100.00 \\
\hline 4 & 0 & 0 & 1.50 & 8.30 & 55.30 & 87.90 & 100.00 \\
\hline 5 & 0 & 0 & 15.30 & 24.00 & 44.20 & 63.50 & 100.00 \\
\hline 6 & 0 & 0 & 1.70 & 16.90 & 34.90 & 35.90 & 72.10 \\
\hline Mean & - & 0.63 & 6.40 & 19.12 & 54.82 & 72.00 & 95.35 \\
\hline \pm SD & - & \pm 1.55 & \pm 5.26 & \pm 6.44 & \pm 12.91 & \pm 20.73 & \pm 11.39 \\
\hline SEM & - & 0.64 & 2.15 & 2.64 & 5.28 & 8.50 & 4.66 \\
\hline T value & - & 0.10 & 2.95 & 7.23 & 10.38 & 8.47 & 20.46 \\
\hline P & - & $>0.1$ & $<0.05$ & $<0.001$ & $<0.001$ & $<0.001$ & $<0.001$ \\
\hline
\end{tabular}

$\mathrm{P}$ - value for $\mathrm{t}$ test.

$\mathrm{P}>0.05$ : non-significant

$\mathrm{P}<0.05$ : significant

$\mathrm{P}<0.01$ : highly significant 
Table ( 2): Effect of different doses (12.5 - $200 \mu \mathrm{g} / \mathrm{kg}$ ) of rocuronium bromide on the gastrocnemius siatio nerve contractions in response to indirect stimulation.

\begin{tabular}{|c|c|c|c|c|c|}
\hline No & $12.5 \mu \mathrm{g} / \mathrm{ml}$ & $25 \mu \mathrm{g} / \mathrm{ml}$ & $50 \mu \mathrm{g} / \mathrm{ml}$ & $100 \mu \mathrm{g} / \mathrm{ml}$ & $200 \mu \mathrm{g} / \mathrm{ml}$ \\
\hline 1 & 0 & 17.80 & 40.00 & 97.00 & 100.00 \\
\hline 2 & 5.00 & 40.00 & 76.30 & 96.20 & 100.00 \\
\hline 3 & 0 & 35.00 & 86.30 & 97.00 & 100.00 \\
\hline 4 & 0 & 21.00 & 77.40 & 97.00 & 100.00 \\
\hline 5 & 2.80 & 11.80 & 90.10 & 100.00 & 100.00 \\
\hline 6 & 0 & 38.40 & 91.10 & 100.00 & 100.00 \\
\hline Mean & 1.30 & 27.33 & 76.93 & 97.87 & 100 \\
\hline \pm SD & \pm 2.13 & \pm 11.95 & \pm 19.17 & \pm 1.68 & 0 \\
\hline SEM & 0.80 & 4.80 & 7.85 & 0.68 & - \\
\hline T value & 1.63 & 5.68 & 9.79 & 143.80 & - \\
\hline P & $<0.1$ & $<0.01$ & $<0.001$ & $<0.001$ & - \\
\hline
\end{tabular}

$\mathrm{P}$ - value for t test.

$\mathrm{P}>0.05$ : non-significant

$P<0.05$ : significant

$\mathrm{P}<0.01$ : highly significant

Table (3 ): Time $(\mathrm{sec})$ of rabbit head drop induced by $1 \mathrm{ml}$ rocuronium bromide $(2.9$ $\mathrm{mg} / \mathrm{sec})$ and $1 \mathrm{ml}$ succinyl choline $(4.9 \mathrm{mg} / \mathrm{sec})$.

\begin{tabular}{|c|c|c|}
\hline & $\begin{array}{c}\text { Recuronium bromide } \\
{[1 \mathrm{ml}(2.9 \mathrm{mg} / \mathrm{sec}]}\end{array}$ & $\begin{array}{c}\text { Succinyl choline } \\
{[1 \mathrm{ml}(4.9 \mathrm{mg} / \mathrm{sec}]}\end{array}$ \\
\hline 1st & 13.59 & 9.48 \\
\hline 2nd & 13.78 & 9.59 \\
\hline 3rd & 14.59 & 10 \\
\hline 4th & 16 & 10.78 \\
\hline 5th & 17 & 11 \\
\hline 6th & 17.1 & 11.8 \\
\hline Mean & 15.34 & 10.44 \\
\hline ISD & \pm 1.57 & \pm 0.91 \\
\hline
\end{tabular}

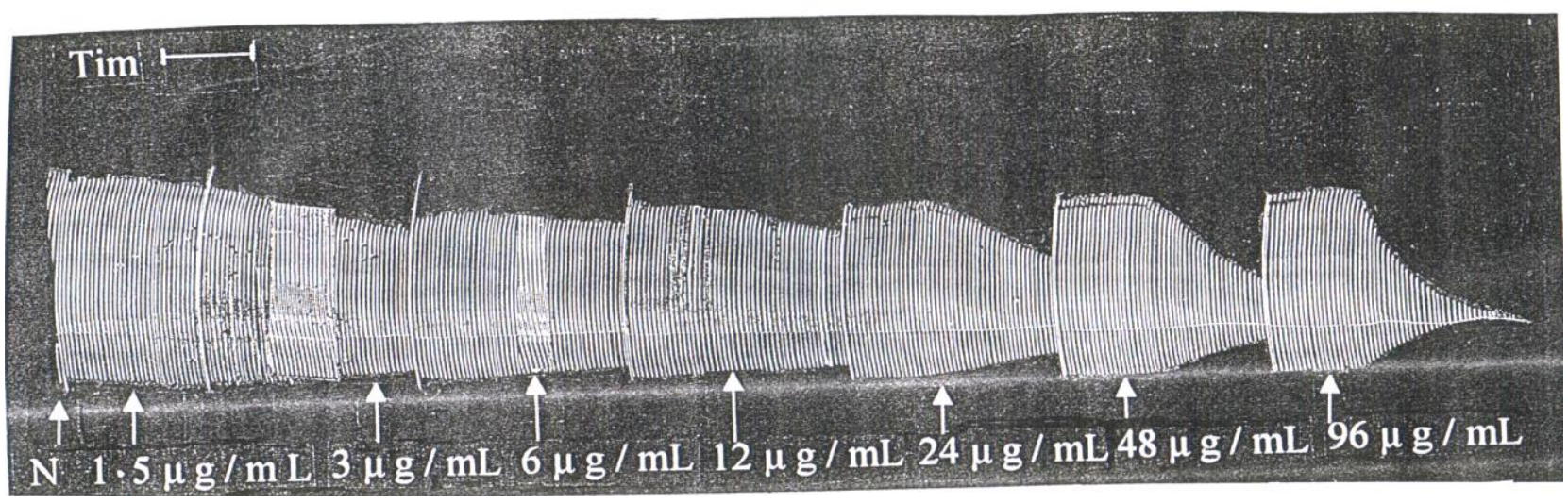

Fig. (l): Effect of different doses of rocuronium bromide on the rat phernic nerve diaphragm contraction $\mathrm{N}=$ Normal. 


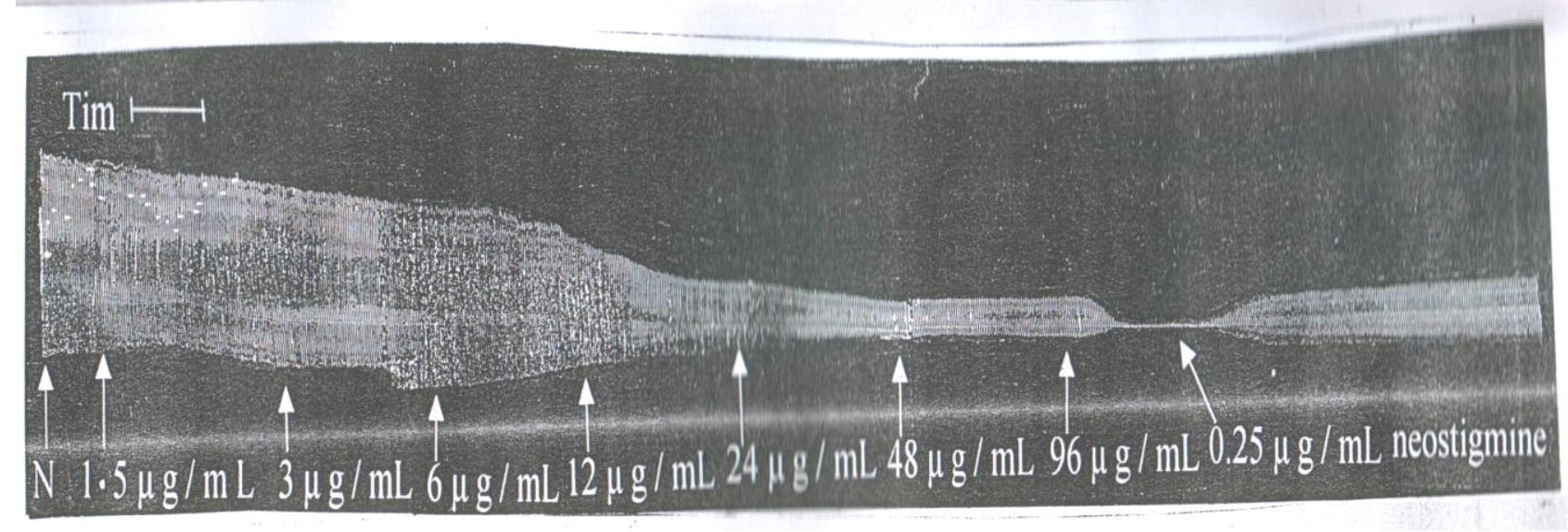

Fig. (2): Effect of cumulative doses of rocuronium bromide on the rat phrenic nerve diaphragm preparation with neostigmine reversal.

$$
\mathrm{N}=\text { NORMAL } .
$$

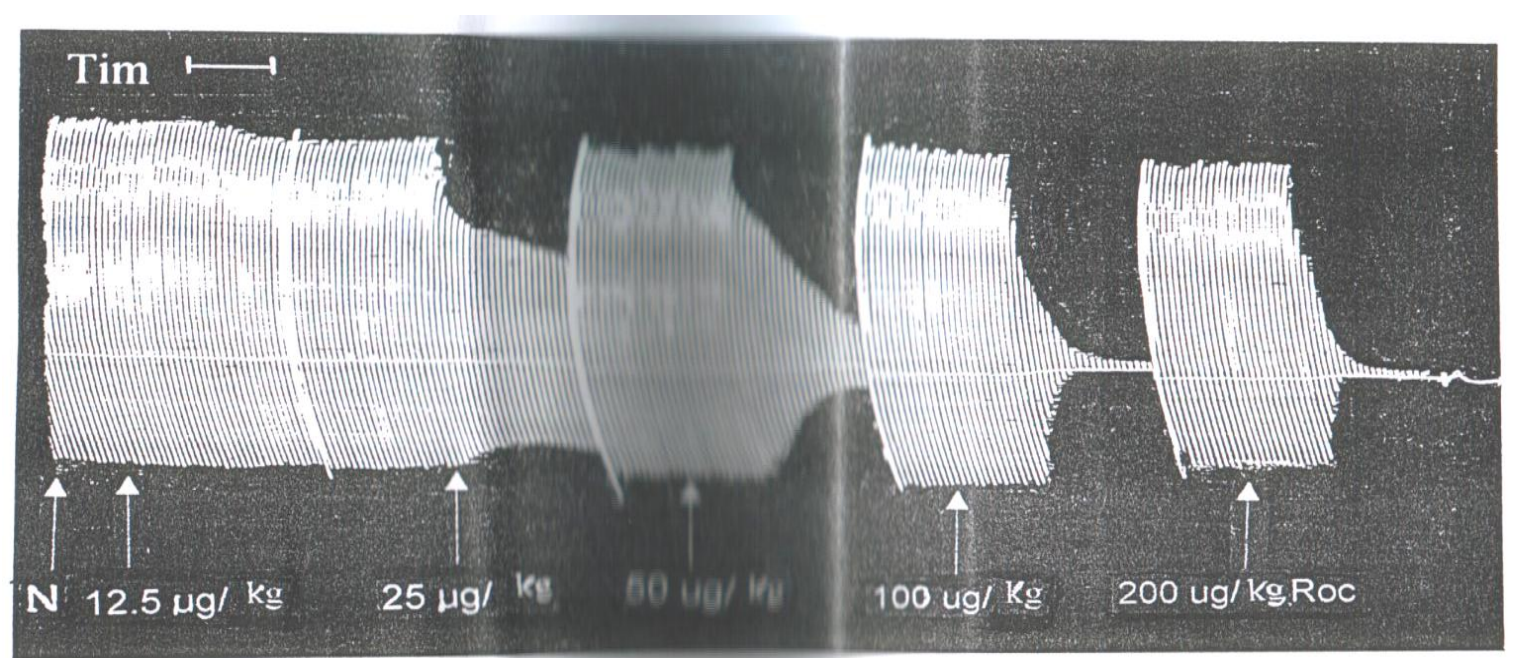

Fig. (3): Effect of different doses of rocuronium bromide on the gasterocnemius sciatic nerve contractions in response to indirect stimulation. $\mathrm{N}=$ Normal

Roc. $=$ Rocuronium bromide. 
Rocuronium bromide

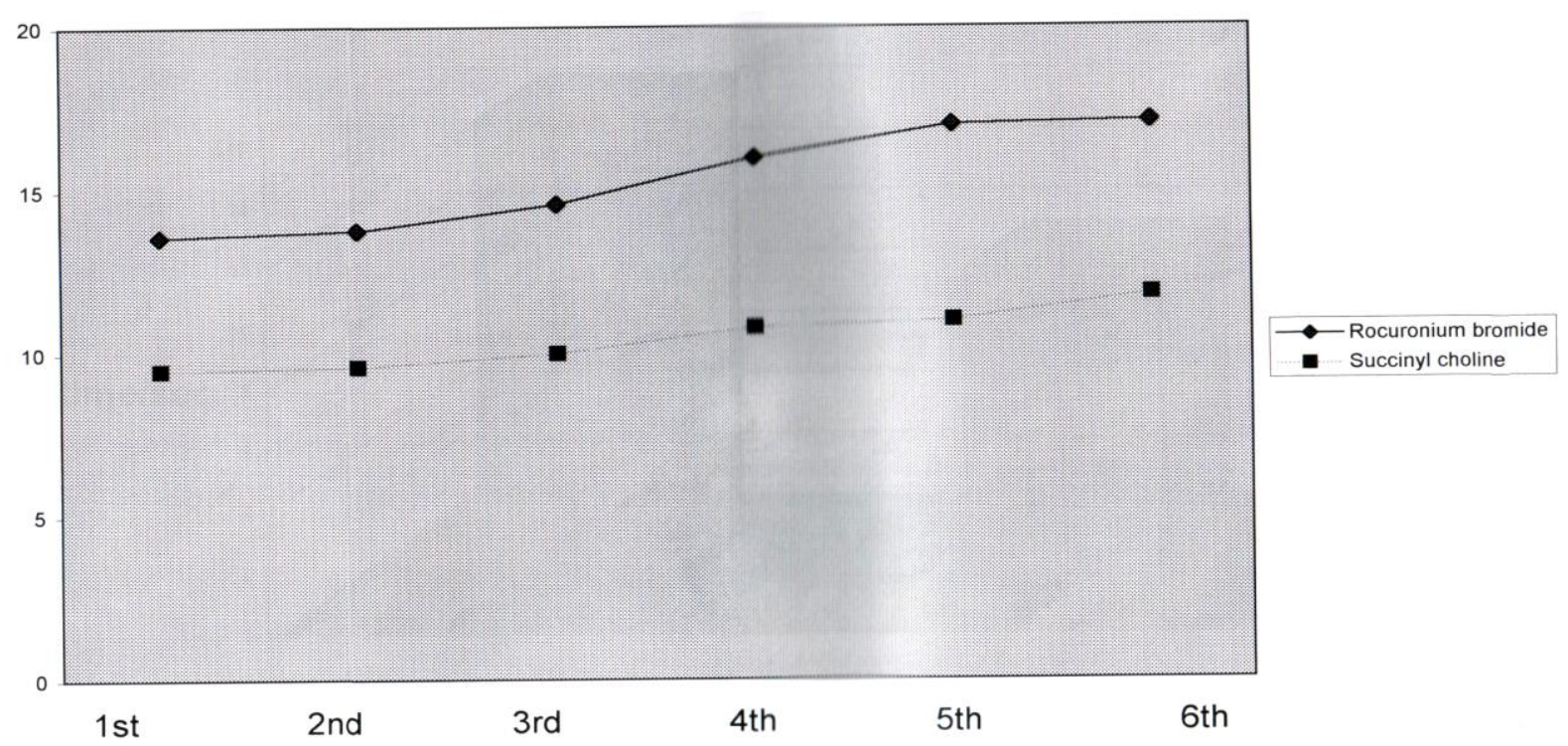

Fig ( 4) : Time ( $\mathrm{sec}$ ) of rabbit head drop induced by $1 \mathrm{ml}$ rocuronium bromide ( 2.9 $\mathrm{mg} / \mathrm{sec}) \& 1 \mathrm{ml}$ succinyl choline $94.9 \mathrm{mg} / \mathrm{sec}$ ).

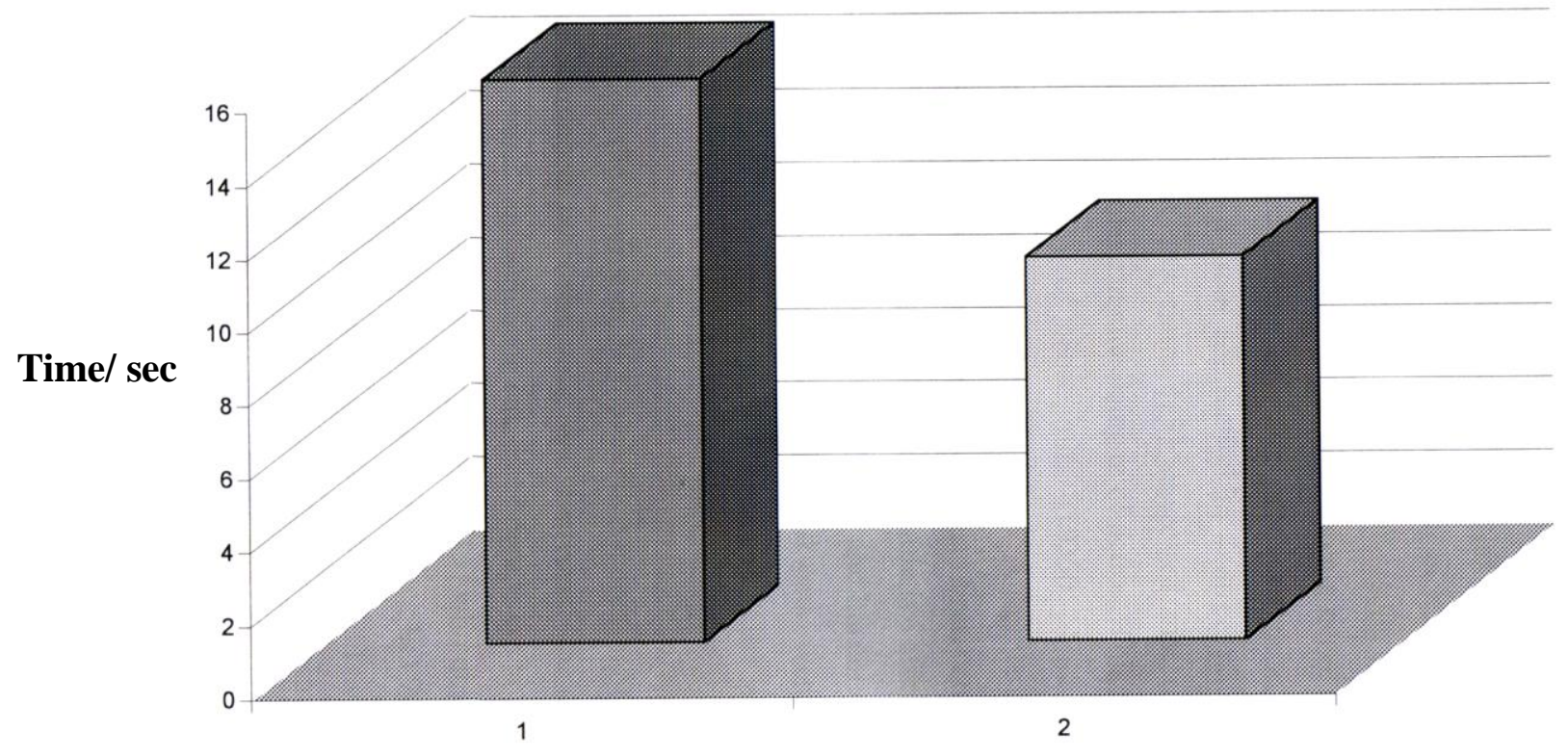

Recuronium bromide

Succinyl choline

Fig (5) : Mean time ( $\mathrm{sec}$ ) of rabbit head drop induced by $1 \mathrm{ml}$ recuronium bromie ( $2.9 \mathrm{mg}$ / sec) \& $1 \mathrm{ml}$ succinyl choline ( $4.9 \mathrm{mg} / \mathrm{sec})$. 


\section{Discussion}

Studies in various anaesthetized animal species have demonstrated that recur onium is a non depolarizing neuro muscular blocker is $5-10$ fold less potent than vecuronium in all species tested. The results of the present study obtained from experiments on isolated rat phrenic nerve diaphragm prepara tion, showed that rocuronium bromide produced dose dependant inhibition of diaphragmatic muscle contraction to indirect phrenic nerve stimulation. Muir and his associates [13] suggested that rocuronium bromide possess a non depolarizing mechanism of action. This hypothesis is strengthened by the ability of neostigmine (ED50 $14 \pm 2 \mu \mathrm{g} / \mathrm{kg}$ ) to completely revers rocuronium induced block in cats. A further study done by Muir et al., [14] on isolated nerve muscle preparation, confirmed his previous study on intact animals. As regards the cumulative effect result of this work is in consistent with the study of Muir and his colleague [15] who found that cumulative effects in anaesthetized cats were observed exclus -ively between first and second consecutive doses, after which there were no major changes in either depth block or time course.

Experiments of the present study showed that increasing the dose of rocuronium had shortened the onset time and increased the duration of action observed in intact anaesthetized cat, these results are in agreement with the results obtained by Muir et al., (1991) [15] who observed that increasing the dose of rocuronium bromide (to 3 times ED 90 blocking dose) had shortened the onset time and increased duration of action 2 to 3 folds in all species which were tested. The rapid onset of neuromuscular block induced by rocuronium has been suggested due to the relatively low potency of the drug [16].

Regarding the site of action. Muir and his collegues 1990 found that rocur onium had been failed to suppress twitches of indirectly stimulated curariz -ed muscules in pigs.

It is likely to be a blocker of neuro muscular transmission rocuronium has no effect on end plate with current dec ay characteristic, indicating a lack of receptor channel block.

Rocuronium antagonizes acetylcholine at the receptors therefore, it is likely that it competes with acetylcholine at its binding site. This has a stabilizing influence on the post synaptic membr ane preventing the development of acti on potential in skletal muscles. [17].

Marshal et al., [5] found that rocuronium does not give preblock twich augmentation in auaesthetized cats and pigs, but induced twitch block which was easily reversed by neosti gmine in anaesthetized cats and in isolated nerve-muscle preparation, in addition fade was observed with tetanic or train of four (TOF) stimulation in the anaesthetized pig and cat. The rabbit head drop experiment had showed that the onset of action of rocuronium was $15.34 \pm 1.57 \mathrm{sec}$. While for succiny lcholine $10.44 \pm 0.91 \mathrm{sec}$. This result is in agreement with that reported previously $[18,19]$.

In clinical practice those authers $[18,19]$ reported that rocuronium bromide had a rapid onset and concluded that it can replace succinylcholine as the muscle released of choice for rapid sequence induction. In addition Baraka et al. [20] and his collogues reported that due to its rapid onset, intermediate duration of action and lack of adverse effects, it is likely that rocuronium is a suitable alternative for such in condition where 
safe, rapid tracheal incubation is required particularly in patient who is at risk of adverse sequalae of succiny lcholine. Reynolds et al. [21]

recommend rocuronium as a non depolarizing NMBA that can provide satisfactory relaxation within three minutes when administered intramuscu -larly in infants and children.

In conclusion rocuronium bromide is the suitable short acting relaxant in all condition, and it can replace succinyl choline in rapid sequence induction.

\section{References:}

1. Wierda JMKH ; de Wit APM ; Huizenga K. and Agoston S. (1990): Clinical observation of the neuromuscular blocking action of Org. 9426, a New steroidal non depolarizing agent. Br. J. Anaesth. 64: 521-523.

2. Shorten G.D.; Uppington, J. and Comunale , M.E. (1998): Changes in plasma catecholamine concentration and haemodynamic effects of rocuron ium and vecuronium in elderly patients Europ. J. Anaesth. 15: 335-341.3.

3. Levy J.H.; Davis, G.K., Duggan J. and Szlam F(l994) : Determination of the haemodynamics and histamine release of rocuronium ( Org. 9426) when administered in increased doses under $\mathrm{N}_{2} \mathrm{O} / \mathrm{O}_{2}$ sufentanil anesthesia. Anesth. Analg. 78: 318-214.

4. Mc Coy, E.P.; Maddineni V.R.; Elliot, P.; Mirkhur R.K. Carson I.W. and Cooper R.A.(l993): Haemod ynamic effect of rocuronium during fenataryl anaesthesia, comparison with vecuronium. Can.J. Anaesth. 40 (8) : 703-708.

5. Marshall R.J. Muir A.W.; Sleigh T. and Sovage D.S. (1994) : An overview of the pharmacology of rocuronium bromide in experimental animals Eur. J. Anaesth. Ll (9) 9-15.
6. Meistelman C. Plaud B. and Donati F. (l944) : A comparison of the neuromuscular blocking effects of rocuronium bromide at the aductor policies and laryngeal adductor Euro. J. Anaesth. 11 (9) : 33-36.

7. Cantineau J.P.; Porte E. ; D'Honnerur G. and Duval-Destin P. (1994) : Neuromuscular effects of rocuronium on the diaphragm and addu -ctor pollicies muscle in anaesthe -tized patients . Anaesthesiol. 81: 585-590.

8. Mc Court K.C. Mirakhur RK and Kerr C.M. (l999) : Dosage of neostigmine for reversal of rocuronium block from two levels spontaneous recovery. Anaesth. 54: 651-5.

9. Cooper R.A. Mirakhur R.K. and Maddineni V.R. (l993): Neuromuscular effects ofrocurronium bromide ( Org. 9426) during fentanyl and halothane anaesthesia. Anaesthesia Analg. 48: 103-5.

10. Bulbring E. (l946) : The phrenic nerve diaphragm preparation of the rat. In: Pharmacological experiment on isolated preparation. Edited by the staff of department of pharmacology, University Edinbrug S.p. 30-31. E \& S. Livingstone, Edinbrugh, London 1970.

11. Brown K.N (l938) : The cat tibialis posterior. In pharmacological experiments on intact preparation. Edited by Staff of the department of Pharmacology, University of Edinb rugh. P. 34-44 E \& S Livingstone Edinbrugh and London 1970.

12. Miller L.C. and Tainter M.L. (l944) : Proc. Soc., Eper, Biol. And. Med. 57: 261.

13. Muir A.W.; Houston J. Green K.L.; Marshall R.J. Bowman W.C. and Marshall I.G. (1989) : Effect of new neuro muscular blocking agent (org. 9426) in anaesthetized cats and pigs, and in isolated nerve-muscle prepar ations Br. J. Anaesth. 63: 400-10. 
14. Muir A.W. and Hreen K.L. (1990) : Effect of a new neuromuscular blockage agent (Org. 9426) in anaeshtetized cats and pigs and in isolated nerve-muscle preparation Br. J. Anaesth. 22: 142-160.

15. Muir A.W. Anderson $K$. and Marshall R.J. (1991): The effects of (rocuronium) analogue of recuronium on neuromuscular transmission in anaesthetized cats, $\operatorname{dogs}$ and monkey and in isolated preparations. Acta Anaesth. Scand. 35: 85-90.

16. Donati (1993) : Effect of dose and potency on onset of action of rocuronium. Anaesthetic phamacology review 1: 34-43.

17. Shiriashi, H. Suzuki H. Suzuki T. Katsumata N. and Agawa S. (1992): Fading responses in the evoked EMG after rocuronium in cats Can. J. Anaesth. 39: 1099-1104.

18. Mirakhur R.K. Cooper A.R. and Clarke R.S.J. (l994): Onset and
Intubating condition of rocuronium Erop. J. Anaesth. 11 (9) 41-43.

19. Tryba M. Zorn A. Thale H. and Zenz M. (l994) : Rapid sequence orotracheal intubation with rocuronium a randomized double blind comparison with suxamethonium preliminary com munication. Eur. J. Anaesth. (9) 44-48.

20. Baraka A.S.; Sajjid S.S. and Assaf B.A. (1997): Thiopental, rocuronium versus ketamine, rocuronium for rapid sequence intubation in parturients unde -rgoing C.S. Anaesth. Analg. 1104-1107.

21. Reynolds L.M.; Brown R. Lurs A. and Fisher D.M. (1996): Intramuscular rocuronium in infant and children dose ranging and tracheal intubating conditions . Anaesthesial. 58: 231-9. 22. Steel R.,K. and Torrier G.H. (l960): Principles and Procedures of statistics Eds MAC Grow and Hall . $1^{\text {st }}$ edition Chapter 8 (479) . Book Company N.Y. 


\title{
الروكورونبيوم بروميا : دراسة فارماكولوجية
}

\author{
* د. معالي محمد حسن جعفري

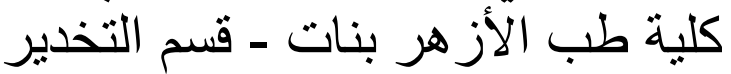

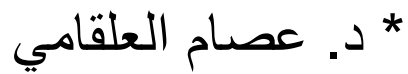 \\ كلية طب القاهرة - قدم الفارماكولوجي
}

أوضح تحليل النتائج في الدراسة الفارماكولوجية أن عقار الروكورونيوم بروميد يسبب إقلال شديد فن

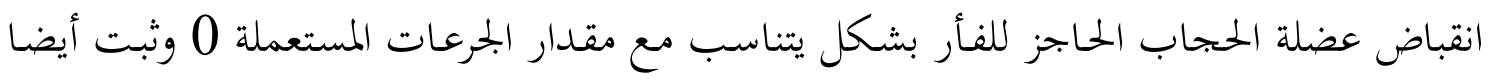

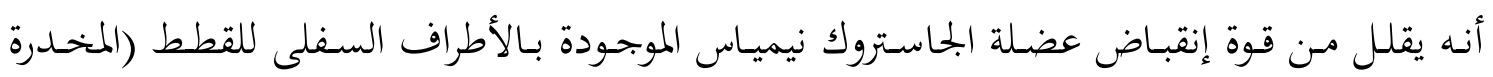

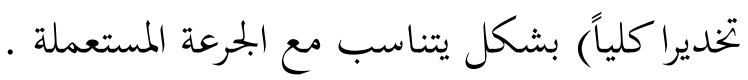

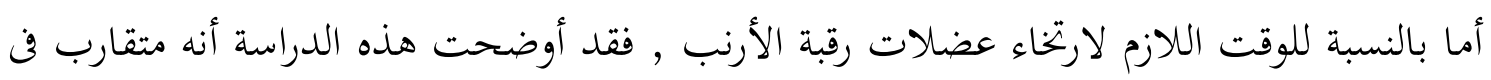

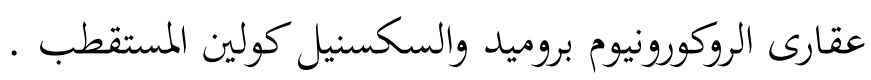

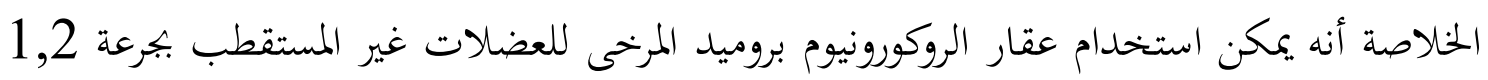

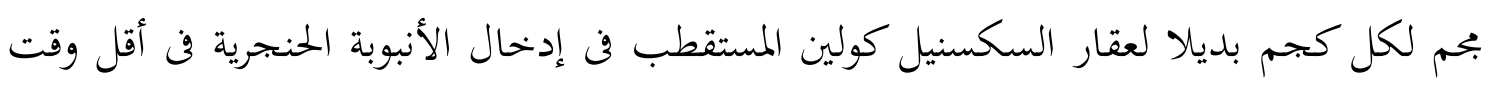

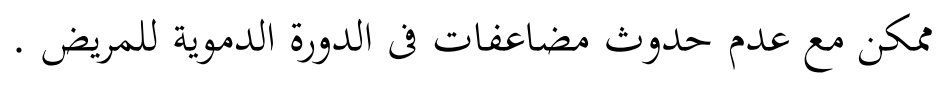

